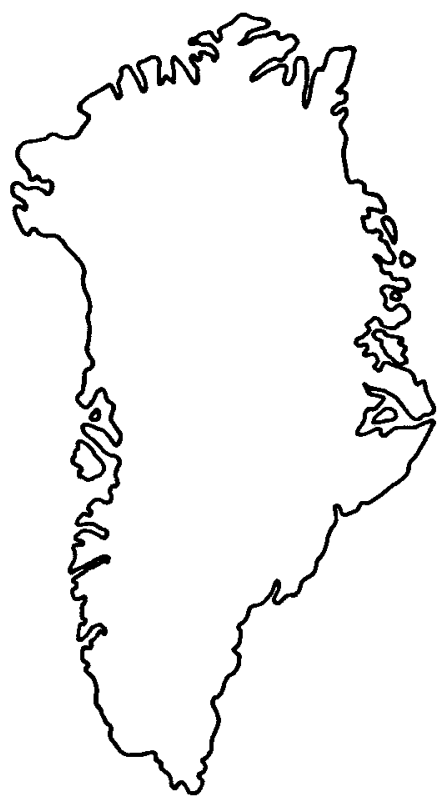

\title{
Silurian trilobites from Peary Land, central North Greenland
}

\author{
Philip D. Lane
}

\begin{abstract}
Five species of trilobites are described from near the top of the Odins Fjord Formation in Peary Land: Opoa ostreata sp. nov., Encrinuroides palasso sp. nov. (for comparison with which the type series of Encrinuroides moderatus (Poulsen, 1934) is refigured), Distyrax peeli gen. et sp. nov. (Encrinuridae), Podowrinella christiei sp. nov. and Gaotania anoplos sp. nov. The age of the fauna and links with other faunas are discussed.
\end{abstract}

P. D. L., Department of Geology, University of Keele, Keele, Staffordshire ST5 5BG, U.K.

In their reconnaissance traverse of the Lower Palaeozoic carbonate platform sequence of Peary Land (fig. 1) in the summer season of 1974, Drs Robert L. Christie (Geological Survey of Canada) and John S. Peel (Geological Survey of Greenland) not only constructed geological sections, but also made preliminary collections of fossils at many horizons (Peel \& Christie, 1975; Christie \& Peel, 1977). The trilobites in this paper are among the first macrofossils from their collections to be systematically described. They are the first Silurian trilobites from Peary Land and the most northerly trilobites of that age to have been figured. Although they occur in a fauna numerically dominated by brachiopods, the trilobites themselves are far more numerous than the other macrofossil groups represented - gastropods, bivalves, rugose and tabulate corals - pelmatozoan debris excepted. Ostracodes are very abundant. These are mostly 'smooth' forms lacking lobation or obvious sculpture; a species of Platybolbina is present.

The collection locality (GGU 184125) lies near the top of the Silurian carbonate sequence in Peary Land, in the Odins Fjord Formation of Hurst (1984), the former un-named Silurian limestone formation (member F; Christie \& Peel, 1977) about $20 \mathrm{~m}$ beneath black shales which here form the basal part of the Wulff Land Formation (Hurst \& Surlyk, 1982). The locality (fig. 1) is that from which Aldridge $(1979$, p. 7) described the conodont fauna.

The limestone when freshly broken is almost black but weathers to a pale buff colour. It is thinly-bedded and the bedding surfaces are very irregular.

\section{The age of the fauna}

The age of the collection as indicated by the conodonts is unequivocal; it is celloni Zone as demonstrated by the occurrence of the eponymous taxon (Aldridge, 1979, p. 10). This zone lies within the Telychian Stage, the highest of the three stages now recognized in the Llandovery Series of the Silurian (Cocks et al., 1984). 


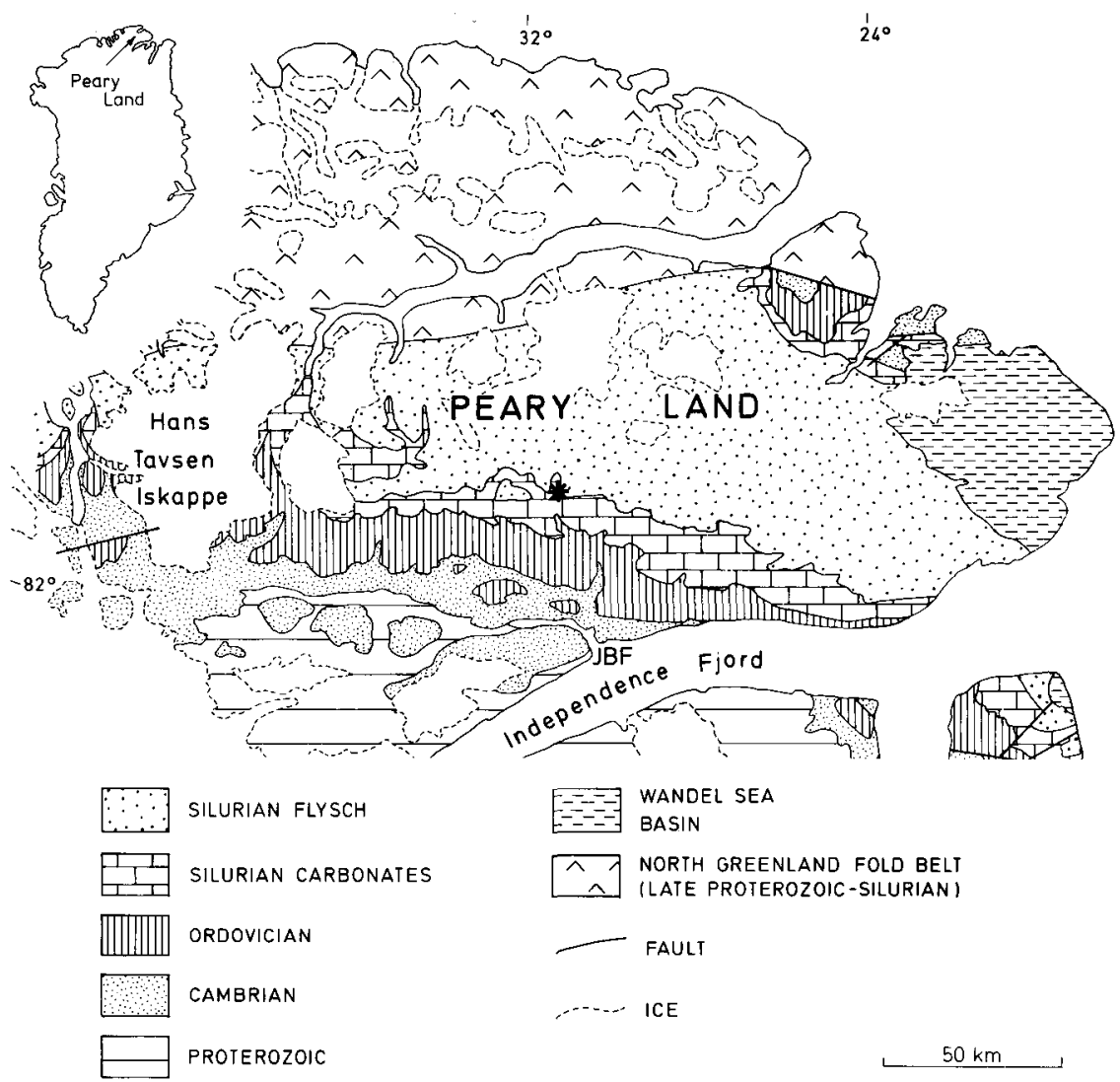

Fig. 1. Peary Land, central North Greenland, showing the collection locality for GGU sample 184125 . JBF, Jørgen Brønlund Fjord.

Two of the trilobite genera represented in the collection (Opoa and Podowrinella) are known otherwise only from their type species (from eastern North Greenland and Scotland, respectively); in both these cases, they are from rocks which may just be as young as earliest Wenlock. Encrinuroides palasso sp. nov., although assigned to a genus which has been somewhat loosely interpreted as the repository for many Ordovician encrinurine species, is closest in morphology to a species from the slightly older Cape Schuchert Formation of Washington Land. Gaotania is previously known from two regions in China, in the southwest (Chang, 1974) and in the north-west (Zhang \& Meng, 1986), and from the Mackenzie Mountains, Canada (Chatterton \& Perry, 1983). It is restricted to Llandovery rocks, as probably is Distyrax gen. nov. which is known also from species which occur in Estonia, Georgia, U.S.A. and Anticosti Island, Canada.

The information from the trilobites is therefore consistent with the conodont evidence, and while providing no additional firm correlation data, makes a late Llandovery age for the fauna most likely. 
The occurrence of the ostracode Platybolbina is, like Encrinuroides, a record of a genus whose species are typically Ordovician, although some Silurian representatives are recorded.

\section{Techniques and preservation}

The trilobites are generally well preserved. However, in the case of all the taxa, there was a strong tendency for the exoskeleton to part from the internal mould, whilst removal of matrix from the external surface of the cuticle proved difficult or impossible. On breaking the limestone the exoskeleton therefore tended to adhere to the external mould; in such specimens it proved exceedingly difficult to remove the exoskeleton without damage. As few natural or casted external moulds were therefore available for study, it will be seen from the illustrations that not all the specimens have been fully prepared; it was considered preferable to leave some matrix adhering to parts of the exoskeleton in some specimens so that the character of the surface sculpture could be illustrated.

\section{Systematic descriptions}

Family Styginidae Vogdes, 1890 [emend. Lane \& Thomas, 1983] Genus Opoa Lane, 1972

Type species. By original designation; Opoa adamsi Lane, 1972, from the late Llandovery (Telychian) or early Wenlock (Sheinwoodian) of Kronprins Christian Land, eastern North Greenland.

Diagnosis. See Lane (1972, p. 340).

Opoa ostreata sp. nov.

Plate 1, figs 1-12

Derivation of name. Latin 'rough', referring to the sculpture.

Holotype. MGUH 16.472 (cranidium).

Figured paratypes. MGUH 16.473-5 (cranidia); MGUH 16.476, 7 (free cheeks); MGUH 16.478 (rostral plate); MGUH 16.479 (hypostome); MGUH 16.480-3 (pygidia).

Other material. GGU 184125.1-8 (cranidia); GGU 184125.9-15 (free cheeks); GGU 184125.16 (rostral plate); GGU 184125.17-25 (pygidia).

Diagnosis. Glabella relatively narrow, frontal lobe less than twice as wide as posterior parallel-sided part. Anterolateral corners of frontal lobe distinctly marked. Preglabellar furrow only present over outer one-quarter of frontal lobe. $3 \mathrm{G}$ at a distance from $2 \mathrm{G}$. Axial furrow distinct. Anterior part of fixed cheek wide, with distinct wide marginal concave zone and distinct furrow. Palpebral lobe large, running from opposite occipital furrow to posterior of $1 \mathrm{G}$. Pygidium (in plan view) relatively long; axis longer than wide. Surface of exoskeleton (except in furrows and muscle impressions) with a coarse sculpture of short to very short terrace ridges, and coarse tubercles, the two sorts of sculpture grading one into the other. 
Description. Glabella convex, posterior half parallel-sided back to occipital ring, which is slightly but noticeably wider (tr.); anterior part expanding markedly forwards to frontal lobe which is rather less than twice the width of posterior part. Occipital muscle impression, $1 \mathrm{G}$ and $2 \mathrm{G}$ all smooth, the latter two confluent and placed close to axial furrow; $3 \mathrm{G}$ small, adjacent to axial furrow and some distance from $2 \mathrm{G}$. Anterolateral parts of glabella distinctly marked, preglabellar furrow only present over lateral one-quarter of anterior of frontal lobe. Surface of glabella with distinct, coarse and largely non-anastomosing terrace ridges which are stronger and transverse towards posterior, and finer and subparallel to anterior margin of glabella anteriorly. Fixed cheek anteriorly with a wide concave marginal zone (on which coarse terrace ridges are exsagittally directed); adaxial to this lies a distinct furrow which joins axial furrow just posterior to widest part of glabella. Palpebral lobe, which is the highest point of the cephalon, semicircular in plan, extending from opposite occipital ring to posterior of $1 \mathrm{G}$. Free cheek with distinct concave marginal zone and furrow which curves back towards posterior of visual surface. Visual surface convex in vertical plane. Sculpture of short to very short terrace ridges, which on border and large genal spine are largely transverse, and on field of free cheek are approximately exsagittally directed.

Pygidium with slender axis, longer than wide, reaching one-third to one-quarter way to posterior margin. Width of pygidium (in dorsal view) greater than length in smaller specimens, but less than this in larger; in plan view, larger specimens are markedly longer than wide. Whole pygidium convex, most so at mid-length and mid-width, giving a 'hump-back' profile. Seven pairs of pleural ribs which widen to margin, and a median posterior rib which is bifid over posterior half; interpleural furrows distinct almost to lateral margins. Axis and distal parts of ribs with a sculpture of short, distinct terrace ridges; proximal parts of ribs with coarse tubercles, the two sorts of sculpture grading one into the other. Doublure placed very close to dorsal exoskeleton, reaching about half way forward sagittally; narrowing to anterolateral corners; outer three-quarters with coarse, distinct 'scalloped' terrace ridges, inner one quarter with coarse ridges aligned approximately concentrically to inner margin of doublure.

Discussion. The most obvious differences by which $O$. ostreata and $O$. adamsi may be distinguished (which are listed in the diagnosis) are superficial. In particular, the very different strongly-developed sculptures of the two species (short terrace ridges in ostreata, honeycomb pattern in adamsi) seduce the eye. Although such sculptural features may be useful discriminators at the species level (as used here) it is the structural features of the axial portion of the exoskeleton which probably provide the best indicators of relationship. In this context the disposition and shape of the glabellar muscle scars are paramount. The closeness of the glabellar scars to the axial furrow seen in ostreata is the 'primitive' condition within the family, since it is here in early members such as Raymondaspis (see Whittington, 1965, pl. 56, fig. 6). The primitive outline of the muscle scars, however, is much more transversely elongate, rather than the quadrate or round outline seen in both $O$. adamsi and ostreata. The great similarity in outline and position of the glabellar muscle scars in these forms is reflected in the generic placement. 
Family Encrinuridae Angelin, 1854

Subfamily Encrinurinae Angelin, 1854

Genus Encrinuroides Reed, 1931

Type species. Cybele sexcostata Salter in Phillips, 1848, p. 343, pl. 8, fig. 10 only. Neotype selected and redescribed by Whittington (1950) from the Sholeshook Limestone, Ashgill (Cautleyan), Dyfed, Wales.

Diagnosis. See Strusz (1980, p. 8).

Encrinuroides palasso sp. nov.

Plate 2, figs 1-8, 10-13; Plate 3, figs 5, 6, 11

Derivation of name. Greek 'bespattered', referring to the random arrangement of the tubercles on the anterior part of the glabella.

Holotype. MGUH 16.484 (cranidium).

Figured paratypes. MGUH 16.485-7 (cranidia); MGUH 16.488-90 (hypostomes); MGUH 16.491-98 (pygidia).

Other material. GGU 184125.26-30 (cranidia); GGU 184125.31 (fixed cheek); GGU 184125.32-36 (pygidia).

Diagnosis. Irregular glabellar tubercles small; glabellar part of pseudoglabellar area with 18 tubercles. Eye peduncle with a few large tubercles at base. Pygidium a little wider than long, triangular. Axis with 18-21 distinct rings, which are narrow laterally, but widen medially, to make inter-ring furrows less distinct, not bearing tubercles. Pleural region with 9-10 pairs of ribs, the last pair meeting behind the terminal piece of the axis.

Description. Occipital ring as wide as cranidium across pseudoglabellar area. Occipital furrow wide, medially composite with $1 \mathrm{~S}$ which is only recognizable as a discrete furrow for a very short distance laterally. Glabella narrowest across $1 S$, evenly widening forward to frontal lobe and farther to pseudoglabellar area where it is almost two-thirds as wide again as across 1S. Ratio of width across pseudoglabellar area to sagittal length of cranidium is 2:3. Glabella gently to moderately convex (tr. \& sag.). Apodemes very deep, especially the anterior pit. 1L small, placed inconspicuously in the almost confluent lateral parts of OS and 1S. $2 \mathrm{~L}, 3 \mathrm{~L}$ and $4 \mathrm{~L}$ large, distinct, somewhat quadrate in outline, overhanging the deep axial furrow. Whole glabella including lateral lobes covered with very distinct, mainly small, but variously sized tubercles, which themselves are distinctly but minutely granulated. Exoskeleton in between these granulated tubercles lacks sculpture. Similar granulate tubercles occur on the pseudoglabellar area, about 18 in number; this area is indistinctly separated from frontal lobe by a shallow furrow. Posterior part of fixed cheek is wide and short, and bears a large genal spine. Field of fixed cheek bears randomly arranged tubercles similar to cranidial ones. Eye opposite 3L. Posterior branch of facial suture trends back from palpebral lobe at about $45^{\circ}$ to transverse line, to near base of genal spine. Eye pedunculate, base of peduncle bearing a few large, granulated tubercles. 
Hypostome subtriangular, dominated by large and convex middle body which is widest adjacent to anterior of anterior wing, and as long (sag.) as maximum width. Rhynchos subquadrate anteriorly, reaching posterior margin of anterior border furrow, wide, and the distinctly delimited part very short. Furrows delimiting rhynchos continue back about two-thirds way to maculae as very indistinct features, which themselves are small but very distinctly raised. Middle furrows confluent across mid line, indistinct. Posterior lobe minute. Anterior border narrow and ridge-like, anterior border furrow wide and distinct. Anterior wings broad and large. Lateral and posterior borders narrow and distinct. Middle body laterally, and anterior of rhynchos have a line of large granulated tubercles; remainder of middle body has granulations, especially medially.

Pygidium triangular, maximum width a little greater than sagittal length. Axis about one-third maximum pygidial width anteriorly, with 18-21 (usually 20 or 21) sharp, ridge-like rings, which widen and flatten medially. No distinct tubercles are borne by these rings. Pleural areas with 9-10 (usually 10) ribs, separated by deep and distinct furrows. Distally, the ribs curve slightly back and become slightly inflated, widen, and here the interpleural furrows become less distinct. The posterior pair of ribs tightly encloses the terminal piece of the axis and form the posterior rounded margin of the pygidium. Axial rings and pleural ribs bear a sculpture of very fine granules.

Discussion. E. palasso is most closely similar to 'Encrinurus' moderatus Poulsen (1934, p. 31, pl. 3, figs 20-22; here Pl. 5, figs 7-14) from the Cape Schuchert Formation (Llandovery) of Washington Land, and Sankt George Fjord, western North Greenland (for synonymy and type data, see below). Differences between the two are of detail, but specific distinction is warranted as discussed below.

In the cephalon the occipital ring of $E$. palasso is shorter and distinctly wider (tr.); $2 \mathrm{~L}$ and $3 \mathrm{~L}$ are rather less prominent and the anterolateral extremity of the frontal lobe of the glabella is more inflated and rounded. More significantly, E. palasso lacks the median anterior glabellar furrow which is short but prominent in $E$. moderatus, and has a wider (exsag.) and more distinct preglabellar furrow. The pygidia of the two forms are practically indistinguishable. They agree well in number of axial rings, pleural rib number and disposition and in general outline and convexity. Although I have described $E$. palasso above as lacking distinct pygidial axial tubercles, and $E$. moderatus was described as possessing a number, the latter form is preserved as internal moulds, and the tubercles are not at all distinct. Internal moulds of $E$. palasso also possess a number of indistinct bosses on the pygidial axis, but these are not evident on the external surface of the exoskeleton.

The generic placement of forms like E. palasso is controversial. Strusz (1980, pp. 8, 10 , 48) commented on the difficulty of recognizing significant constant differences between Encrinuroides, Encrinuraspis and Cromus. He preferred to recognize Encrinuraspis as a junior subjective synonym of Cromus also in discussing $E$. moderatus, and in view of the eye position (opposite 3S) and the pygidial shape, he inclined to a position for the species in Cromus.

I am attracted to the suggestion by Gass (in Strusz, 1980, p. 48) that E. moderatus and therefore now the very similar E. palasso might best be placed in Encrinuroides. Not only is an eye position opposite $3 \mathrm{~S}$ not particularly forwardly-placed for what I consider to be a late member of this genus, but the pygidium is not particularly wide and short for an Encrinuroides species; in fact in general form the pygidium of $E$. palasso is very similar to that of 
Encrinuroides neuter Evitt \& Tripp (1977, p. 130, pl. 11, figs 2-4, 10) from the Middle Ordovician of Virginia, U.S.A.

\section{Encrinuroides moderatus (Poulsen, 1934)}

Plate 5, figs $7-14$

1934 Encrinurus moderatus n. sp., Poulsen, p. 31, pl. 3, figs 20-22.

1980 Cromus? moderatus Poulsen, 1934; Strusz, p. 56.

1980 Encrinuroides? moderatus; Gass in Strusz, p. 56.

Holotype. MMH 3273, cranidium (PI. 5, figs 7a-c) from the Cape Schuchert Formation (Aeronian; mid Llandovery), Sankt George Fjord, western North Greenland.

Paratypes. Cranidium: MGUH 16.350 from the same horizon and locality as the holotype. Pygidia: MMH 3274, 3275, MGUH 16.351, 16.533 from the same horizon and locality as the holotype; MGUH 16.532 from the same formation, Kap Hamilton, Washington Land, western North Greenland.

Other paratypes. All from the Cape Schuchert Formation. MMH 1984.444 (pygidium; Kap Hamilton); MMH 1984.446-451 (pygidia; Sankt George Fjord).

Remarks. A comparison with the most similar form, E. palasso sp. nov., is made above.

\section{Genus Distyrax gen. nov.}

Derivation of name. Greek 'two' and 'spike at rear end' referring to the pygidium; gender feminine.

Type species. Distyrax peeli gen. et sp. nov.

Other species. D. americana (Vogdes, 1886), D. elegantula (Billings, 1866), D. pilistverensis (Rosenstein, 1941), D.? quinquecostata (Mannil, 1958).

Diagnosis. Glabella with large and subquadrate $2 \mathrm{~L}-4 \mathrm{~L}$; the rest of the glabella covered with irregularly-distributed tubercles. Cranidial part of pseudoglabellar area indistinctly separated from glabella. Eye peduncle opposite 3L. Tubercles of cephalon are themselves covered in minute distinct granules, whilst no granules appear between. Hypostome with large convex middle body; rhynchos short and quadrate, not reaching anterior margin. Maculae small but very distinct. Rhynchos and flanking anterior portions of middle body with large irregular granulated tubercles. Middle furrows confluent across mid line. Pygidium very convex with many axial rings of which about the anterior half have complete inter-ring furrows reaching axial furrow, the rest of the inter-ring furrows remote from the axial furrow and the posterior ones merely indicated by pits. Six or seven pairs of pleural ribs (see discussion below), anterior 5 pairs end in small free spines, the fifth of which form a terminal spine-pair. Sixth pair coalesce behind the axis and are enclosed by the pair in front. A possible seventh pair is enclosed by these.

Discussion. A combination of distinctive characters warrants the erection of this new genus. The randomness of the distribution of glabellar tubercles on even the posterior parts of the 
glabella is unusual, although it is seen in some species of what may be the related genera Cromus Barrande, 1852 and Perryus Gass \& Mikulic, 1982. Such a random arrangement is presumably a convergent character since it is also seen on the anterior parts of some species of Frammia Holtedahl, 1914, Encrinuroides Reed, 1931 (see above) and Encrinurus species such as $E$. hagshawensis Lamont, 1965 (see Howells, 1982, pl. 9, figs 4, 9); that species also resembles $D$. peeli in having rather small glabellar tubercles, with the lateral glabellar lobes themselves tuberculate. Distyrax and Perryus also have similar cephalic sculpture (low tuberculated tubercles), weak preglabellar furrows, similar eye position, inconspicuous $1 \mathrm{~L}$, and a markedly convex pygidium (see Gass \& Mikulic, 1982, pl. 1). The pygidium of Distyrax, however, is quite unlike any other encrinurine in the combination of a large number of axial rings and a small number of pleural ribs, and in the possession of a bifid terminal spine-pair. In some of these latter respects the pygidium has some resemblance to such Ordovician cybelines as Bevanopsis (e.g. B. ulrichi Cooper, 1953; see Evitt \& Tripp, 1977, pl. 16) and Cybeloides (e.g. C. virginiensis Cooper, 1953; see Evitt \& Tripp, 1977, pl. 20 ). In view of the presence in cybelines of anterior pleural bands in the pygidium which are lacking in Distyrax and the general encrinurine morphology of the cephalon, such resemblance is considered to be superficial. Thus, Distyrax is referred to the Encrinurinae. In $D$. peeli and $D$. elegantula it is difficult to decide on the homology of a narrow, exsagittallydirected, paired structure which lies towards the back of the axis. It is a smooth area which lies adaxial to the sixth pair of pleural furrows and abaxial to the pits which delimit the posterior 10-12 axial rings. Although it may belong to the axis (the pits having migrated from the axial furrow) it is possibly a seventh pleural rib.

Distyrax peeli sp. nov.

Plate 2, fig. 9; Plate 3, figs 1-4, 7-10, 12

Derivation of name. For Dr John S. Peel.

Holotype. MGUH 16.499 (pygidium).

Figured paratypes. MGUH 16.500-502 (cranidia); MGUH 16.503 (hypostome); MGUH 16.504 (free cheek); MGUH 16.505-8 (pygidia).

Other material. GGU 184125.37-40 (cranidia); GGU 184125.41 (free cheek); GGU 184125.42 (hypostome); GGU 184125.43-48 (pygidia).

Diagnosis. Glabellar tubercle formula $1 \mathrm{~S}-\mathrm{O}_{\mathrm{R}}^{\mathrm{F}} ; 2 \mathrm{~S}-1 ; 2^{\mathrm{F}} ; 3 \mathrm{~S}-1_{\mathrm{R}}^{\mathrm{F}}$; tubercles anterior to this random. Pseudoglabellar area with 8 large, symmetrically-arranged tubercles. 1S, $2 S$ and $3 S$ short and transverse, longer on internal mould. Palpebral lobe opposite 3L. Pygidial axis with 35 rings, posterior 12-14 inter-ring furrows represented only by pits. Pleural ribs wide and flat-topped, separated by very narrow furrows. Pygidial sculpture of randomly-scattered distinct pits.

Description. Occipital ring almost as wide as cranidium across pseudoglabellar area, transverse, only shortening slightly behind occipital apodeme. Occipital furrow short, deep and distinct. Glabella narrowest across $1 \mathrm{~S}$ apodemes where it is two-thirds the width across the 

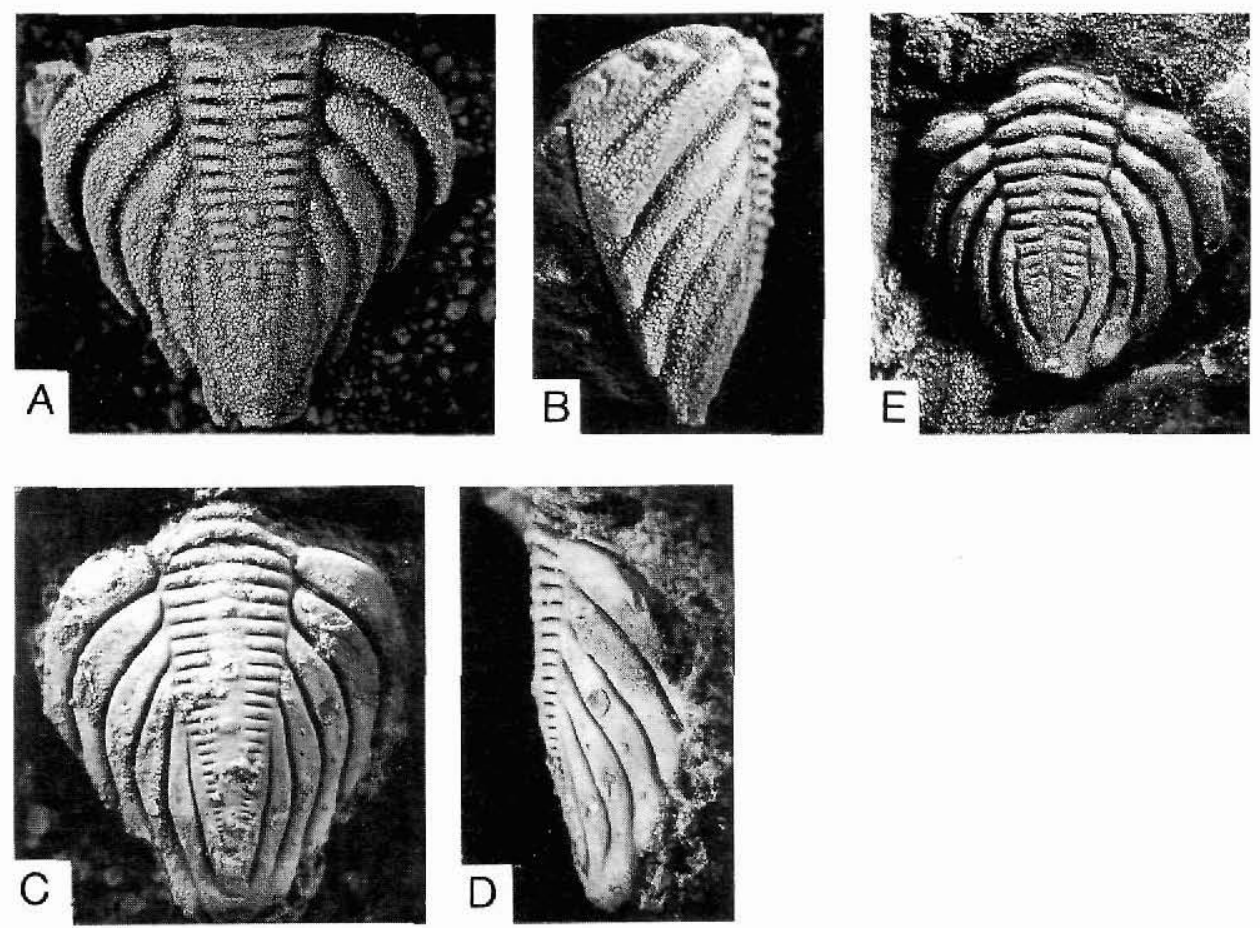

Fig. 2. A-D, Distyrax pilistverensis (Rosenstein, 1941). A, B, the holotype (Rosenstein, 1941, pl. 4, figs 5, 6; Mannil, 1958, pl. 8, figs 1,2) in dorsal and left-lateral views, Tr 1880, $\times 3$. C, D, the unlocalised specimen figured by Mannil (1958, pl. 8 , fig. 3 in plan and right-lateral views, Tr 1879, $\times 4$. E, Distyrax? quinquecostata (Mannil, 1958) in plan view, $\operatorname{Tr} 1877, \times 5$. All photographs by Dr. Reet Mannil (Geological Institute, Tallinn, Estonia) in which institute the specimens are deposited.

frontal lobe and a little over half the width across the pseudoglabellar area. Ratio of width of cranidium across pseudoglabellar area to sagittal length 4:5. Glabella moderately convex (tr.); in lateral view, posterior of occipital ring is higher than sagittal line adjacent to $1 \mathrm{~L}$, in front of $2 \mathrm{~L}$ moderately convex. Apodemes distinct. Glabellar tubercles in front of $3 \mathrm{~L}$ with no clear pattern. Cranidial part of pseudoglabellar area with 8 large symmetrically-arranged tubercles. Fixed cheek triangular, convex; field with many tubercles. Palpebral lobe opposite $3 \mathrm{~L}$. Posterior section of facial suture trends with very slight sigmoidal curvature backwards and outwards at about $45^{\circ}$. Genal spine narrow.

Hypostome subtriangular. Middle body widest adjacent to large anterior wing; rhynchos short, not reaching anterior margin, only clearly delimited anteriorly. Anterior border sharp, vertical and ridge-like especially laterally; anterior border furrow deep and distinct. Maculae small, but very distinct and posteriorly placed. Middle body with low, large and irregularly-placed tubercles, which are increasingly indistinct posteriorly.

Pygidium triangular, very convex, maximum width about equal to sagittal length in plan view. Axis about one-third maximum anterior width anteriorly, with up to 35 rings indicated of which the anterior 15-16 have inter-ring furrows reaching the axial furrow and shallowing medially; behind this, inter-ring furrows are remote from the axial furrow and the median 
line and the posterior few are represented by mere pits. A weak tubercle occurs on about every fourth ring, with weaker paired tubercles on some of the rings between. Pleural regions with 6 pairs of ribs which are wide and have little dorsal convexity, separated by narrow, distinct furrows which widen marginally. The anterior 5 pairs end in small, backwardly-directed free spines, of which the fifth pair form terminal spines which are very close together. This fifth pair encloses the sixth pair which themselves meet behind the posterior of the axis; a seventh pair may be present. The ribs on external mould have many, randomly sized and placed pits which on the internal mould are more numerous, larger, and more distinct.

Discussion. I am grateful to G. D. Edgecombe for correspondence leading to the present association of encrinurine cephala and pygidia described in this fauna, and to him and $\mathrm{K}$. $\mathrm{C}$. Gass for bringing to my attention additional species which appear to be congeneric with $D$. peeli.

D. elegantula (from photographs provided by K. C. Gass) differs from the type species in a number of characters. Overall, the cranidium is relatively shorter and the glabellar tubercles are much larger, flatter and less distinct. The pygidial axis has about 25 rings - only the posterior 4 or 5 of which are indicated by pit-like inter-ring furrows. In addition, the pleural ribs (the possible seventh is present in this species) are much more convex dorsally, and separated by wider furrows. The pitted pygidial sculpture of the type species is apparently lacking.

From the available illustrations of $D$. pilistverensis (see Rosenstein, 1941, pl. 6, figs 5, 6; Mannil, 1958, pl. 8, figs 1-3) and the description provided by Vogdes (1886) of $D$. americana, both of these species lack the possible seventh pygidial pleural rib. The former species has about 30 axial rings (of which very few, perhaps 5, are separated by complete inter-ring furrows), the latter "... 20 or more axial rings; the first 13 extend entirely across ..." (Vogdes, 1886, p. 1). Encrinurus quinquecostatus Mannil, 1958 (Mannil, 1958, pl. 8, fig. 10; herein fig. 2E) should possibly also be included in Distyrax. The number of both pleural ribs and axial rings in the latter species is smaller, however, being about 5 and about 15 respectively. All these species are of late Llandovery age.

Family Pterygometopidae Reed, 1905

Genus Podowrinella Clarkson, Eldredge \& Henry, 1977

Type species. By original designation; Phacops straitonensis Lamont, 1965 from the Knockgardner Formation (late Llandovery (Telychian) or early Wenlock (Sheinwoodian)) of the Blair-Straiton district near Girvan, Strathclyde, the Ree Burn Formation (?late Llandovery), Hagshaw Hills, and the Deerhope Formation (late Llandovery), North Esk Inlier, Pentland Hills, Lothian, Scotland.

Diagnosis. See Clarkson et al. (1977, p. 134). 
Podowrinella christiei sp. nov.

Plate 4, figs $1-16$

Derivation of name. For Dr Robert L. Christie.

Holotype. MGUH 16.509 (cephalon).

Figured paratypes. MGUH 16.510-16 (cephala); MGUH 16.517-24 (pygidia).

Other material. GGU 184125.49-54 (fragmentary cephala).

Diagnosis. Anterior outline of the cephalic margin, the glabella and between them the facial suture is rounded-angular. Frontal lobe weakly delimited anteriorly. In lateral view, anterior sagittal profile sharply-rounded. Axial furrows from $1 \mathrm{~L}$ forwards diverge at $45^{\circ}\left( \pm 5^{\circ}\right)$. Two elements of $3 \mathrm{~S}$ almost co-linear, trending obliquely at $60^{\circ}$ to sagittal line. Frontal lobe with large, low tubercles. Pygidium with up to 14 axial rings and 8 pleural ribs.

Description. Glabella as long as maximum width, and about three-quarters this width across 1L. Anteriorly, glabella rounded angular and weakly delimited by very shallow preglabellar furrow. In lateral view occipital ring highest point on sagittal line, then intercalating ring which is only a little higher than $1 \mathrm{~L}$ which has a weak independent convexity; anterior profile sharply rounded sagittally in lateral view. Axial furrow distinct, diverging at $45^{\circ}\left( \pm 5^{\circ}\right)$. Occipital furrow deep, as is $1 \mathrm{~S}$ laterally. $1 \mathrm{~L}$ small, node-like; $2 \mathrm{~S}$ just isolated from axial furrow, almost transverse. 3S bipartite, adaxial part short, curved concave backwards and almost co-linear with abaxial part on a line trending at $60^{\circ}$ to sagittal direction; abaxial part deeper and wider, confluent with axial furrow. Frontal lobe bears small, short, slit-like pits arranged in two curved rows after the fashion of rounded invaginations in species of Acernaspis and Calyptaulax (see Eldredge, 1971). On the internal mould, a more or less indistinct furrow links the adaxial ends of $2 \mathrm{~S}$ and $3 \mathrm{~S}$ giving $2 \mathrm{~L}$ and $3 \mathrm{~L}$ slight independent convexity. Posterior border lengthening (exsag.) to rounded genal angle; posterior border furrow short (exsag.). Lateral border furrow wide (tr.) and becoming more so anteriorly; lateral border narrow. Palpebral lobe highest point of cephalon, semicircular in outline reaching from adjacent to anterior pit to close to posterior border furrow. A strong furrow is developed posterior to palpebral lobe, which then curves sigmoidally away to follow posterior section of facial suture. Facial suture of typical course; anterior section crosses axial furrow to run parallel to and between frontal lobe and anterior margin. Visual surface nearly vertical, in this plane with little or no curvature; the single complete surface has a lens formula of $3455565655555554432-19$ files, 87 lenses in all. Vincular furrow weak, interrupted medially. Notches not detected. Hypostomal suture transverse. Whole surface microgranular. Frontal lobe with large, low tubercles which are imperforate. Lateral border furrow with large irregular pits, field of fixed and free cheeks with similar yet generally smaller and less densely-packed pits.

Pygidium rounded, less than twice as wide as long. Axis anteriorly a little more than one-quarter maximum width, gently narrowing and reaching to near posterior margin. It bears up to 14 rings of which the anterior 6 or 7 are distinct because of well-developed apodemes. Approximately the anterior 5 bear on their posterior edge clear traces of 
non-functional articulating half rings. Behind, rings get less distinct and are not separated by apodemes but of impressed scars. A small indistinct post-axial ridge is present. Pleural region with up to 8 ribs of which the anterior 6 are distinct. They widen only slightly distally, reach to near the lateral and posterior margins and have a median row of closely-spaced pits which form a pleural furrow on the internal mould. Interpleural furrows are narrow and distinct. No border or border furrow is developed. Sculpture is of microgranules.

Discussion. P. christiei differs from the type and only other species referred to the genus in a large number of details. The rounded-angular outline of the frontal lobe, facial suture and anterior margin, the almost co-linear elements of $1 \mathrm{~S}$, the non-truncated genal angles and the weaker vincular furrow characterize its cephalon. In addition, there is a difference in the lens formulae given, although it is known in only one specimen of $P$. christiei; unlike $P$. straitonensis, $P$. christiei has 19 files, and never more than 6 lenses in any one. The pygidia of the two forms are easily distinguished. Although it is difficult to compare the overall outline because of the relatively poor preservation of the type species, the axis of $P$. christiei is a little narrower in proportion and has the rings more clearly marked posteriorly, although a similar number appear to be present. The pleural ridges are also more clearly delimited, as are the pleural furrows; up to 8 are present in $P$. christiei, only 4 in $P$. straitonensis.

Clarkson et al. (1977, p. 139) discussed the morphological characters in this genus. They concluded that on current classification, a mixture of characters was present in the type species, so that assignment to the Phacopidae or Pterygometopidae was possible. One character, the meeting at a point of the anterior branches of the facial suture, is not present in $P$. christiei, in which a smooth curve is described. Another character said to be more phacopid-like in $P$. straitonensis, the loss of clear pleural furrows in the pygidium, can possibly be explained by the state of preservation of the Scottish material. Even in the much better preserved Greenland species, the pleural pygidial furrows are variably developed, and they are much fainter on internal moulds (see P1. 4, figs 9-16). It would seem likely, therefore, that these two characters are not of primary importance in delimiting the families mentioned. The suggestion of Eldredge (1971) that the Phacopidae and Pterygometopidae are very closely related is thus reinforced. The total range of variation exhibited by these two families is much smaller than is shown even between subfamilies of other families referred to the Phacopina - for example the Cheiruridae.

I do not think, however, that the presently accepted cheirurid subfamilies should be raised in taxonomic level, for the fundamental shared morphology of genera presently referred to the Cheiruridae is obvious. Fundamental similarity of morphology is also shared by such groups as Phacopidae and Pterygometopidae. 


\author{
Family Odontopleuridae Burmeister, 1843 \\ Subfamily Odontopleurinae Burmeister, 1843 \\ Genus Gaotania Chang, 1974 \\ [Synonym: Stelckaspis Chatterton \& Perry, 1983]
}

Type species. By original designation; Gaotania ovata Chang, 1974 from the Llandovery of south-west China.

Diagnosis. (Emended from Chang, 1974, and Chatterton \& Perry, 1983 (diagnosis of Stelckaspis)). Odontopleurid trilobites with a fused facial suture in holaspis stages. Glabella with occipital lobes, isolated $1 \mathrm{~L}$, and smaller uncircumscribed $2 \mathrm{~L}$. Eyes extending from anterior or mid $1 \mathrm{~L}$ to anterior or mid occipital ring. Genal spines stout, of moderate length, exsagittally or just abaxially posteriorly directed. Cephalic border spines short or represented by tubercles.

Discussion. The present material requires the slight emendation of the diagnosis of cephalic characters. Other parts of the exoskeleton are diagnosed in Chatterton \& Perry (1983, p. 32). Gaotania anoplos lacks clear cephalic border spines; coarse tubercles (Pl. 5, fig. 4c) in a similar position to border spines in other Gaotania species are thought to be their homologue and could have served the same function. In some species of the genus a posterior occipital band is present (see discussion of $G$. anoplos sp. nov. below).

\title{
Gaotania anoplos sp. nov.
}

Plate 5, figs 1-6

Derivation of name. Greek, 'lightly armed soldier' referring to the lack of distinct cephalic border spines.

Holotype. MGUH 16.525 (cephalon).

Figured paratypes. MGUH 16.526-29 (cephala); MGUH 16.530 (free cheek).

Other material. GGU 184125.55-58 (fragmentary cephala).

Diagnosis. A species of Gaotania with small and narrow 1L, wide lateral cephalic border lacking distinct spines. Eye (which extends from mid 1L to mid occipital ring) is highest point of the cephalon; occipital ring with clear posterior band.

Description. Cephalic width:length ratio 5:2. Axial furrow deep adjacent to $1 \mathrm{~L}$ elsewhere only slightly impressed. Median portion of anterior margin concave. Lateral margins (including genal spines) straight, exsagittally directed. Glabella widest at occipital ring, which has a posterior band, narrowing forward. Occipital furrow distinct, very wide laterally. Occipital lobes small and indistinctly marked posteriorly. 1L small, distinctly delimited from median glabellar lobe, especially in smaller specimens. $1 \mathrm{~L}$ more than twice as long as wide. $2 \mathrm{~L}$ very small, not circumscribed. Glabella anterior to this narrow. Anterior pit deep and 
distinct placed adjacent to anterior extremity of glabella. Anterior and anterior border furrow narrow markedly in front of glabella. Lateral border and border furrows distinct, the latter narrower. Border very broad at base of genal spine which is stout, curved and ovate in section. Eyes small but abruptly raised from cheek, extending from mid 1L to mid occipital ring, set at about their own width from axial furrow and forming highest point of glabella. Weak eye ridge runs from anterior of palpebral lobe to anterior of glabella. Border spines absent; a row of rather irregular low tubercles lie on doublural part of border towards base of genal spine in the position border spines occur in other Gaotania species. Lateral border has scattered punctae. Posterolateral parts of border, and genal spine have a few large scattered granules. Such granules also occupy the space between the eye and axial furrow, and a small glabella has similar ones especially posteriorly.

Discussion. The characters in the diagnosis serve easily to distinguish this species from the type species and the five described by Chatterton \& Perry (1983). The cephalon of the type species has more divergent genal spines, relatively larger $1 \mathrm{~L}$ and the anterior margin has an small quadrate anterior projection. Of the five species described by Chatterton \& Perry, it is closest to Gaotania warreni, but as compared to that the glabella overall and its lobes are narrower, the borders and border furrows wider, there are no clear border spines, the eye ridge is less distinct, the eye forms the highest point of the cephalon and it extends from mid $1 \mathrm{~L}$ to mid occipital ring.

A single, small free cheek has been found (PI. 5, fig. 2). It demonstrates both the relatively coarser sculpture often seen in young stages of trilobites, and the typical feature that the facial suture becomes ankylosed late in ontogeny, probably within the holaspis stage.

The occurrence in G. anoplos of a posterior occipital band is unusual in a genus referred to the Odontopleurinae since such a character is taken to be typical of members of the Miraspidinae. In $G$. anoplos it is presumably a derived character since it is not described in any of the older species from Canada, although incipient development of it may be seen in Gaotania warreni (Chatterton \& Perry, 1983, pl. 17, fig. 14; pl. 18, fig. 2). The taxonomic importance of this character for the discrimination of subfamilies might therefore be impared, and care must be exercised to determine that if present, the posterior occipital band was not secondarily acquired in genera now referred to the Miraspidinae. Its function remains arcane.

Acknowledgements. I thank B. D. E. Chatterton, G. D. Edgecombe, R. A. Fortey, K. C. Gass, G. J. Helbert, D. J. Holloway, R. M. Owens, David J. Siveter and A. T. Thomas, all of whom at different times suggested improvements to earlier drafts of this paper.

\section{References}

Aldridge, R. J. 1979: An upper Llandovery conodont fauna from Peary Land, eastern North Greenland. Rapp. Grønlands geol. Unders. 91, 7-23.

Billings, E. 1866: Catalogues of the Silurian fossils of the Island of Anticosti with descriptions of some new genera and species, $93 \mathrm{pp}$. Montreal: Geological Survey of Canada.

Chang, W. T. 1974: [Silurian Trilobita]. In Nanking Institute of Geology and Palaeontology (edit.) [ $A$ handbook of the stratigraphy and palaeontology in southwest China], 173-187, pls 80-85. Peking (Beijing): Science Press, Academia Sinica [in Chinese]. 
Chatterton, B. D. E. \& Perry, D. G. 1983: Silicified Silurian odontopleurid trilobites from the Mackenzie Mountains. Palaeontogr. Can. 1, 128 pp.

Christie, R. L. \& Peel, J. S. 1977: Cambrian-Silurian stratigraphy of Børglum Elv, Peary Land, eastern North Greenland. Rapp. Grønlands geol. Unders. 82, 48 pp.

Clarkson, E. K. N., Eldredge, N. \& Henry, J.-L. 1977: Some Phacopina (Trilobita) from the Silurian of Scotland. Palaeontology 20, 119-142.

Cocks, L. R. M., Woodcock, N. H., Rickards, R. B., Temple, J. T. \& Lane, P. D. 1984: The Llandovery Series of the type area. Bull. Br. Mus. (Nat. Hist.) Geology. 38, 131-182.

Eldredge, N. 1971: Patterns of cephalic musculature in the Phacopina (Trilobita) and their phylogenetic significance. J. Paleont. 45, 52-67.

Evitt, W. R. \& Tripp, R. P. 1977: Silicified Middle Ordovician trilobites from the families Encrinuridae and Staurocephalidae. Palaeontographica A157, 109-174.

Gass, K. C. \& Mikulic, D. G. 1982: Observations on the Attawapiskat Formation (Silurian) trilobites of Ontario, with description of a new encrinurine. Can. J. Earth Sci. 19, 589-596.

Howells, Y. 1982: Scottish Silurian trilobites. Monogr. Palaeontogr. Soc. London, 1-76.

Hurst, J. M. 1984: Upper Ordovician carbonate shelf stratigraphy, facies and evolution, eastern North Greenland. Bull. Grønlands geol. Unders. 148, 73 pp.

Hurst, J. M. \& Surlyk, F. 1982: Stratigraphy of the Silurian turbidite sequence of North Greenland. Bull. Grønlands geol. Unders. 145, 121 pp.

Lane, P. D. 1972: New trilobites from the Silurian of north-east Greenland, with a note on trilobite faunas in pure limestones. Palaeontology 15, 336-364.

Mannil, R. M. 1958: [Trilobites of the Families Cheiruridae and Encrinuridae from Estonia]. GeoloogiaInst. Uurim. 3, 165-212 [in Russian].

Peel, J. S. \& Christie, R. L. 1975: Lower Palaeozoic stratigraphy of southern Peary Land, eastern North Greenland. Rapp. Grønlands geol. Unders. 75, 21-25.

Phillips, J. 1848: The Malvern Hills compared with the Palaeozoic districts of Abberley. Mem. geol. Surv. Gt Britain 2(1), 386 pp.

Poulsen, C. 1934: The Silurian faunas of North Greenland. I. The fauna of the Cape Schuchert Formation. Meddr Grønland 72,2(1), 46 pp.

Rosenstein, E. 1941: Die Encrinurus-Arten des estlandischen Silurs. Tartu Ulik Geoloogia-Inst. Toimet. 62, 49-77.

Strusz, D. L. 1980: The Encrinuridae and related trilobite families, with a description of Silurian species from southeastern Australia. Palaeontographica A168, 1-68.

Vogdes, A. W. 1886: Description of a new Crustacean from the Clinton Group of Georgia, with remarks upon others, $5 \mathrm{pp}$. New York City.

Whittington, H. B. 1950: Sixteen Ordovician genotype trilobites. J. Paleont. 24, 531-565.

Whittington, H. B. 1965: Trilobites of the Ordovician Table Head Formation, western Newfoundland. Bull. Mus. comp. Zool. Harvard 132, 275-442.

Zhang Wen-tang \& Meng Xian-song 1986: [Silurian trilobites from Xichuan, Henan]. Acta Palaeont. Sinica 25, 507-514 [in Chinese with English summary]. 


\section{Plate 1}

All specimens are from GGU locality 184125 , central Peary Land, and are housed in the Geological Museum, Copenhagen (MGUH prefix).

\section{Opoa ostreata sp. nov.}

Figs 1a-c. MGUH 16.472. Holotype cranidium; dorsal, anterior and oblique-lateral views, $\times 2$.

Fig. 2. MGUH 16.473. Paratype cranidium, latex cast; dorsal view, $\times 2$.

Figs 3a, b. MGUH 16.474. Paratype cranidium; dorsal and oblique anterior views, $\times 2$.

Fig. 4. MGUH 16.476. Paratype free cheek, latex cast; ventral view, $\times 1.5$.

Figs 5a, b. MGUH 16.479. Paratype hypostome; oblique lateral and ventral views, $\times 5$.

Fig. 6. MGUH 16.475. Paratype cranidium, latex cast; oblique-lateral view, $\times 4$.

Fig. 7. MGUH 16.478. Paratype rostral plate, latex cast; ventral view, $\times 3$.

Fig. 8. MGUH 16.477. Paratype free cheek; lateral view, $\times 2$.

Fig. 9. MGUH 16.480. Paratype pygidium, latex cast; dorsal view, $\times 4$.

Fig. 10. MGUH 16.481. Paratype fragmentary pygidium; dorsal view, $\times 3$.

Fig. 11. MGUH 16.482. Paratype pygidium; dorsal view, $\times 2$.

Fig. 12. MGUH 16.483. Paratype fragmentary pygidium; dorsal view, $\times 2$. 

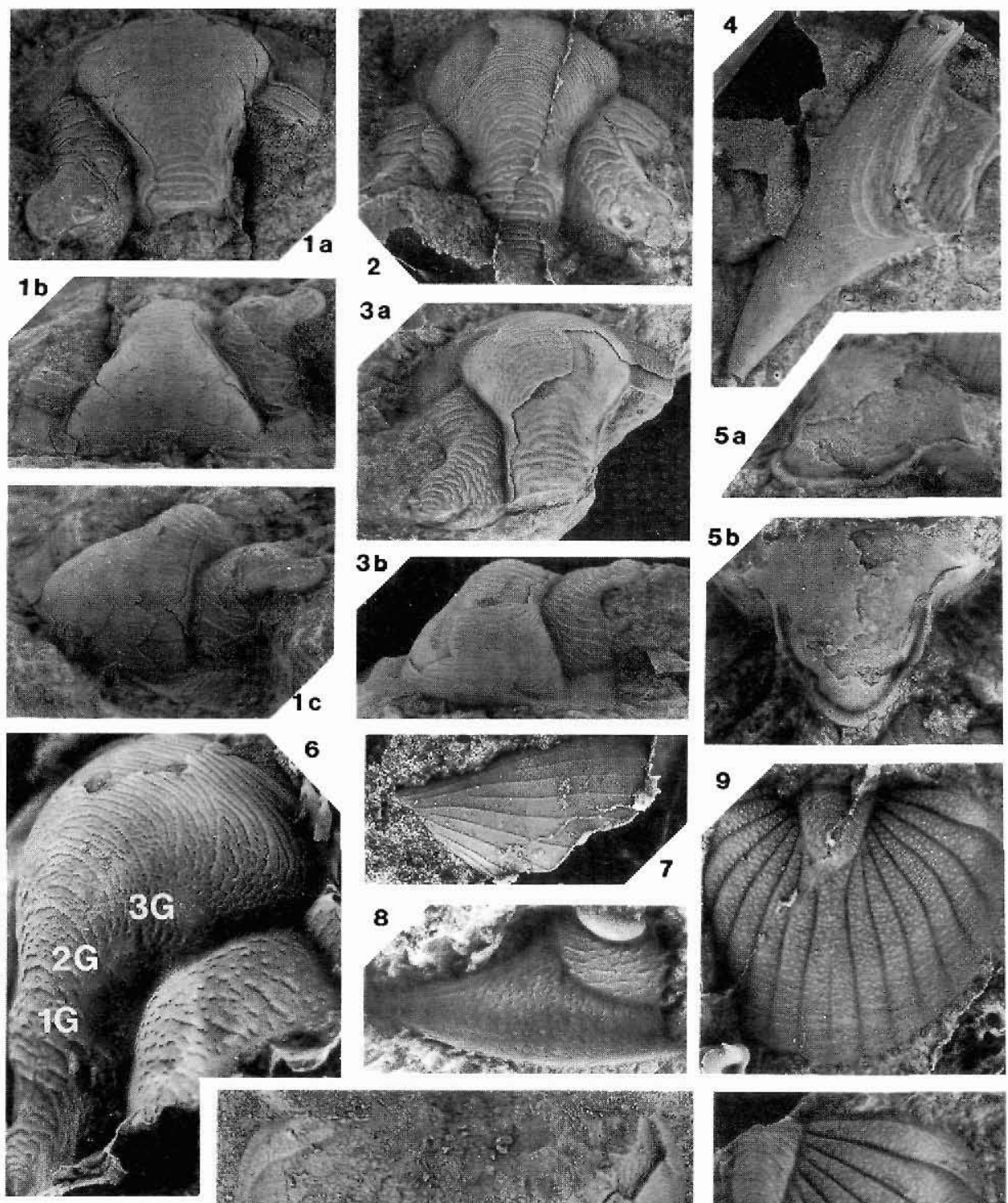

10
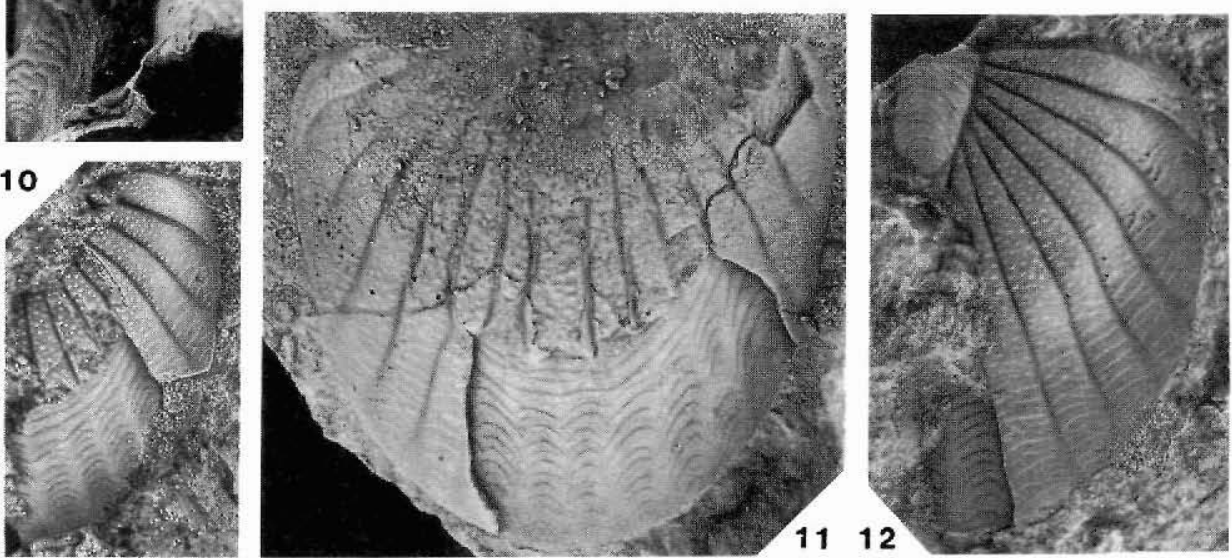


\section{Plate 2}

All specimens are from GGU locality 184125, central Peary Land and are housed in the Geological Museum, Copenhagen (MGUH prefix).

\section{Encrinuroides palasso sp. nov.}

Figs 1a-d. MGUH 16.484. Holotype cranidium; dorsal, oblique-anterior, lateral and magnified lateral views. 1a-c, $\times 3 ; 1 \mathrm{~d}, \times 6$.

Fig. 2a, b. MGUH 16.485. Paratype fragmentary cranidium, latex cast; dorsal views. $2 a, \times 3 ; 2 b, \times 12$.

Fig. 3. MGUH 16.486. Paratype fragmentary cranidium; dorsal view, $\times 3$.

Figs 4a, b. MGUH 16.488. Paratype hypostome; lateral, ventral and anterior views, $\times 3$.

Figs 5a, b. MGUH 16.491. Paratype pygidium; dorsal and plan views, $\times 3$.

Figs 6a-d. MGUH 16.492. Paratype pygidium; dorsal, right-lateral, plan and left-lateral views, $\times 3$.

Figs 7a-c. MGUH 16.493. Paratype pygidium; lateral, plan and dorsal views, $\times 3$.

Figs 8a, b. MGUH 16.494. Paratype pygidium; posterior, lateral and dorsal views, $\times 3$.

Figs 10a, b. MGUH 16.495. Paratype pygidium; dorsal and ventral views, $\times 3$.

Fig. 11. MGUH 16.496. Paratype pygidium; dorsal view, $\times 3$.

Figs 12a-c. MGUH 16.497. Paratype pygidium; lateral, posterior and dorsal views, $\times 3$.

Figs 13a-d. MGUH 16.498. Paratype pygidium; plan, right-lateral, left-lateral and dorsal views, $\times 3$.

Distyrax peeli gen. et sp. nov.

Fig. 9. MGUH 16.504. Paratype free cheek; oblique-anterior view, $\times 3$. 

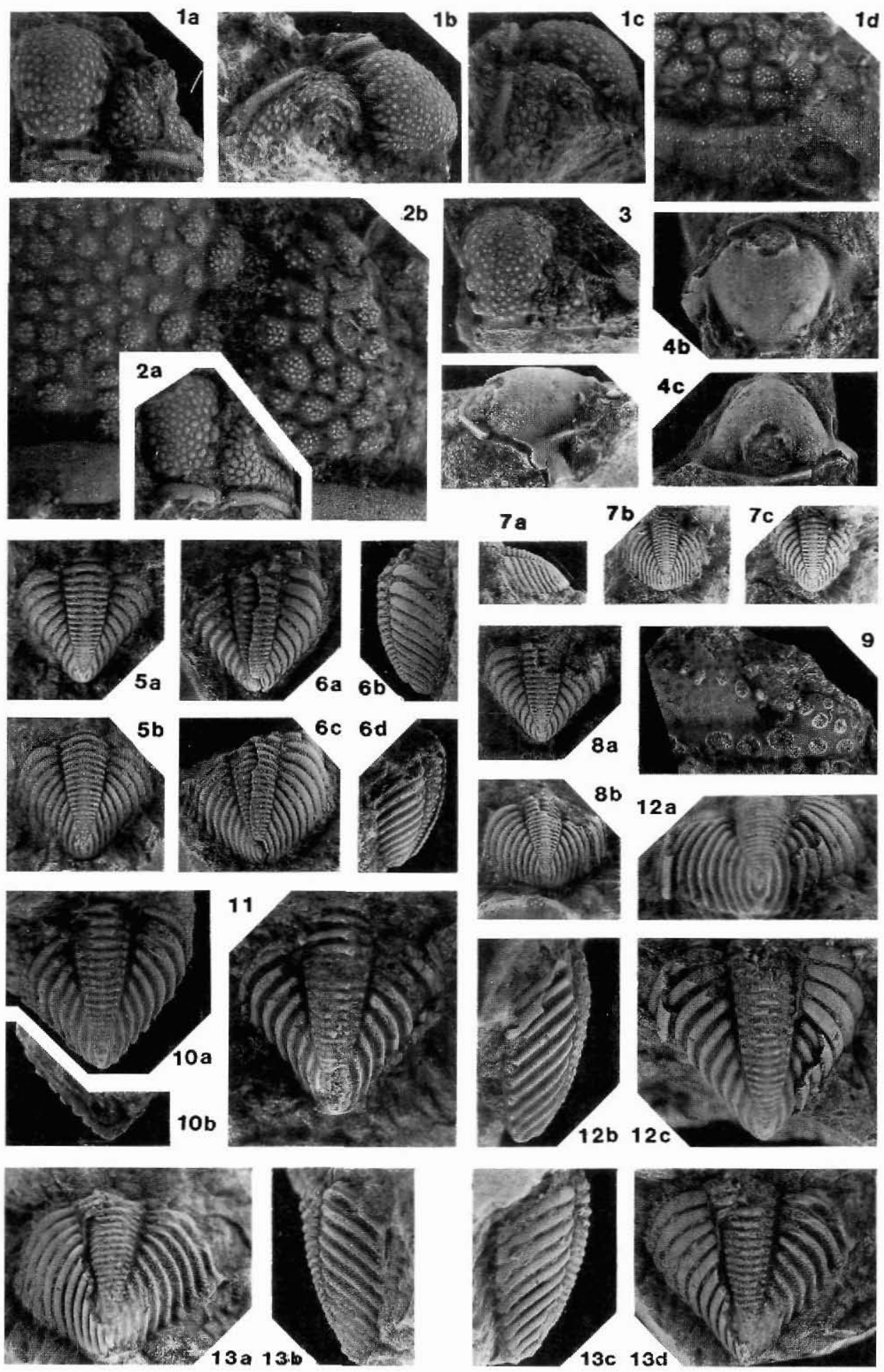


\section{Plate 3}

All specimens are from GGU locality 184125, central Peary Land and are housed in the Geological Museum, Copenhagen (MGUH prefix).

Distyrax peeli gen. et sp. nov.

Figs 1a-d. MGUH 16.500. Paratype cranidium; dorsal, lateral and anterior views, $\times 3$.

Fig. 2. MGUH 16.501. Paratype fragmentary cranidium, latex cast; dorsal view, $\times 3$.

Fig. 3. MGUH 16.502. Paratype fragmentary cranidium; dorsal view, $\times 3$.

Figs 4a-c. MGUH 16.503. Paratype hypostome; ventral and left-lateral views, $\times 3$.

Figs 7a, b. MGUH 16.505. Paratype pygidium; plan views. 7a, $\times 3 ; 7 \mathrm{~b}, \times 5$.

Figs 8a, b. MGUH 16.499. Holotype pygidium; plan views. $8 \mathrm{a}, \times 3 ; 8 \mathrm{~b}, \times 5$.

Figs 9a, b. MGUH 16.506. Paratype pygidium; lateral and plan views, $\times 3$.

Fig. 10. MGUH 16.507. Paratype pygidium; ventral view, $\times 3$.

Figs 12a, b. MGUH 16.508. Paratype pygidium; plan and lateral views, $\times 3$.

Encrinuroides palasso sp. nov.

Fig. 5. MGUH 16.487. Paratype fragmentary cranidium; dorsal view, $\times 3$.

Figs 6a, b. MGUH 16.489. Paratype hypostome; ventral and right-lateral views, $\times 3$.

Figs 11a-c. MGUH 16.490. Paratype hypostome; left-lateral, anterior and ventral views, $\times 3$. 

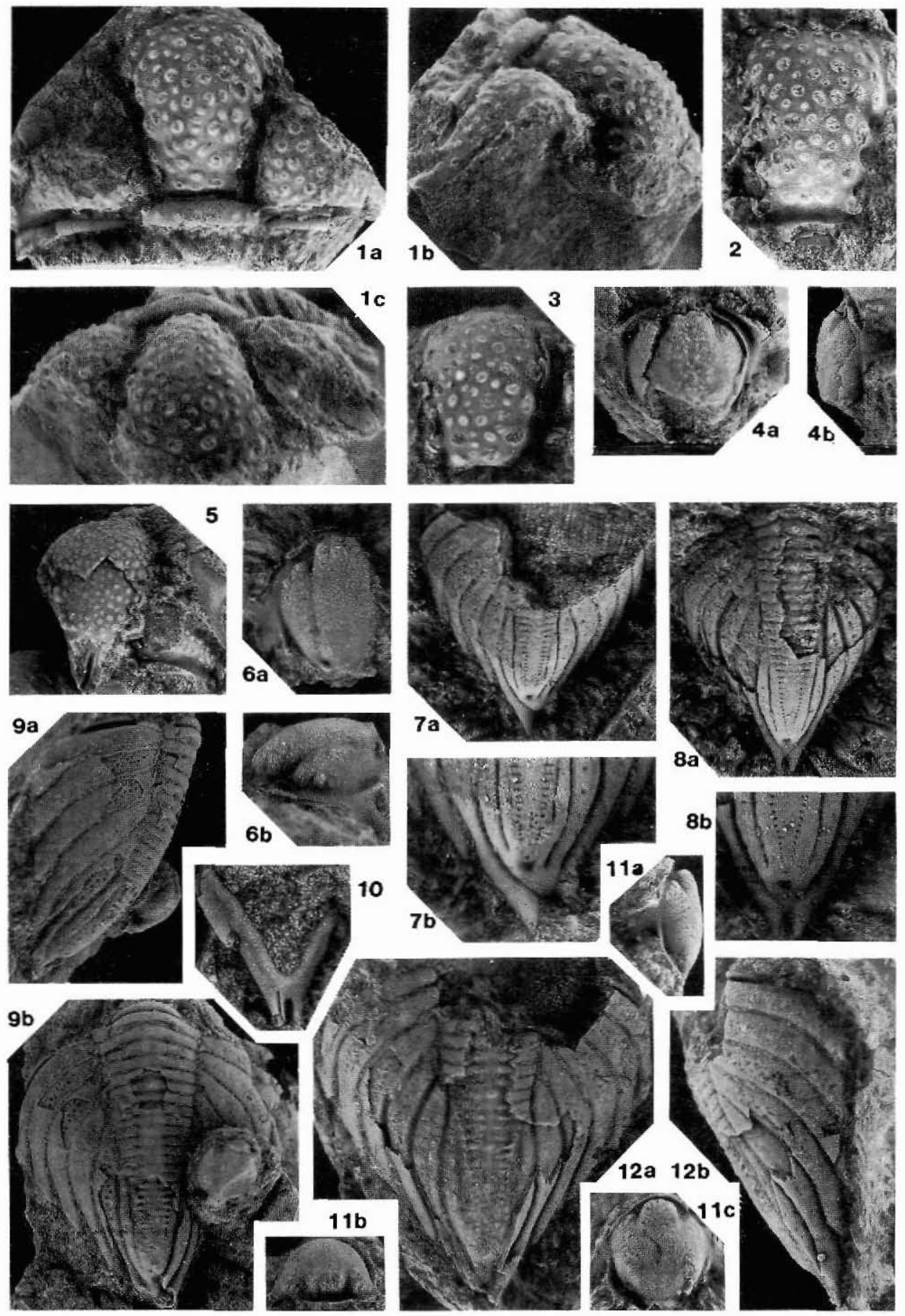


\section{Plate 4}

All specimens are from GGU locality 184125 , central Peary Land and are housed in the Geological Museum, Copenhagen (MGUH prefix). All figures (except 2b), $\times 3$.

\section{Podowrinella christiei sp. nov.}

Figs 1a-c. 16.509. Holotype cephalon; dorsal, anterior and oblique-lateral views.

Figs 2a, b. MGUH 16.510. Paratype fragmentary cephalon; dorsal and oblique-lateral views. $2 b, \times 10$.

Figs 3a, b. MGUH 16.511. Paratype fragmentary cephalon; dorsal and oblique-lateral views.

Figs 4a, b. MGUH 16.512. Paratype fragmentary cephalon; dorsal and oblique-anterior views.

Figs 5a, b. MGUH 16.513. Paratype fragmentary cephalon; dorsal and anterior views.

Figs 6a, b. MGUH 16.514. Paratype fragmentary cephalon; dorsal and ventral views.

Figs 7a, b. MGUH 16.515. Paratype fragmentary cephalon; dorsal and ventral views.

Fig. 8. MGUH 16.516. Paratype fragmentary cephalon; dorsal view.

Fig. 9. MGUH 16.517. Paratype pygidium; dorsal view.

Fig. 10. MGUH 16.518. Paratype pygidium; dorsal view.

Fig. 11. MGUH 16.519. Paratype pygidium; dorsal view.

Fig. 12. MGUH 16.520. Paratype pygidium; dorsal view.

Fig. 13. MGUH 16.521. Paratype pygidium; dorsal view.

Figs 14a, b. MGUH 16.522. Paratype pygidium; dorsal and lateral views.

Fig. 15. MGUH 16.523. Paratype pygidium; dorsal view.

Fig. 16. MGUH 16.524. Paratype pygidium; dorsal view. 

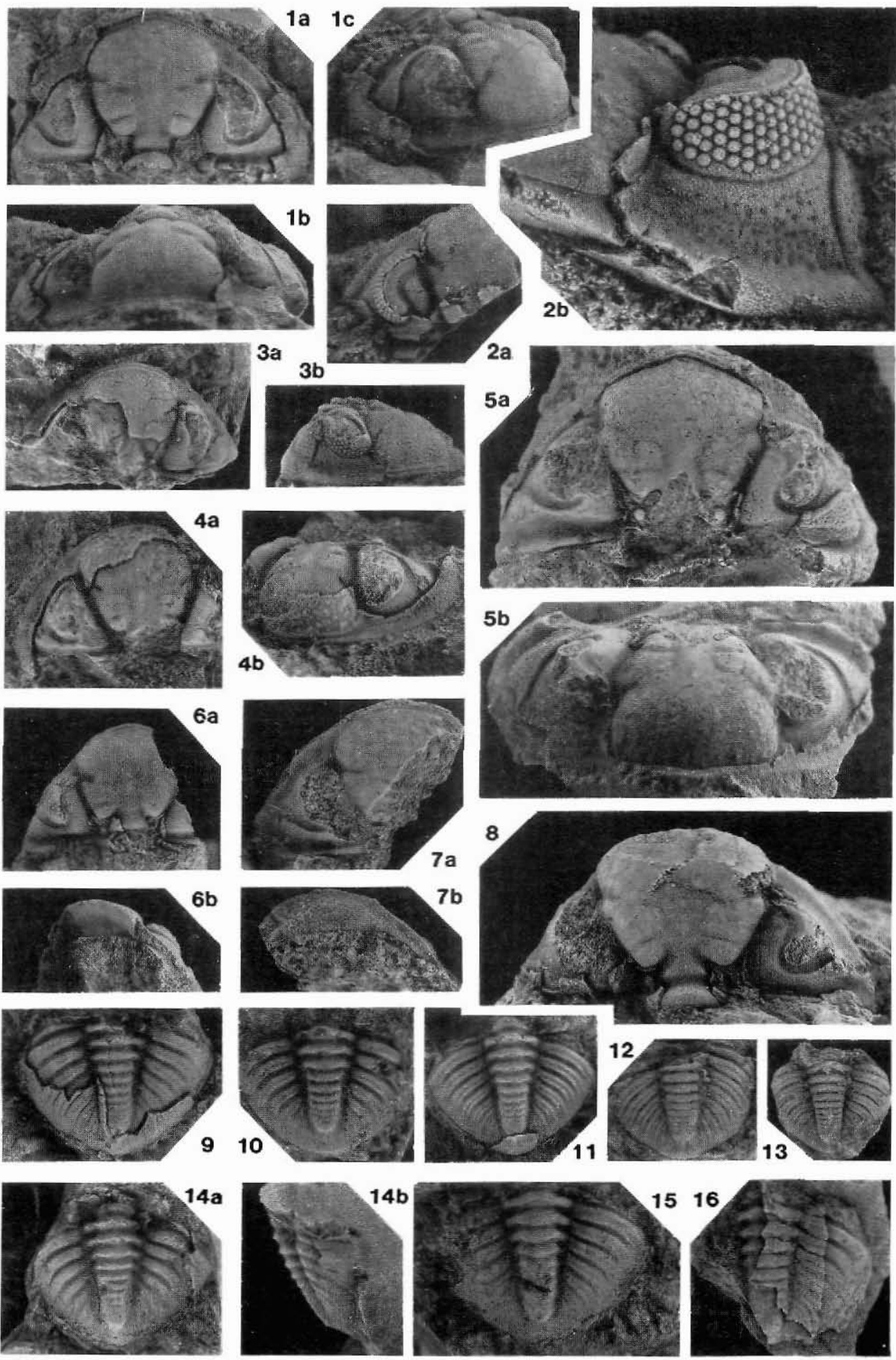


\section{Plate 5}

All specimens are from GGU locality 184125 , central Peary Land, and are housed in the Geological Museum, Copenhagen (MGUH prefix).

Gaotania anoplos sp. nov.

Figs 1a-c. MGUH 16.525. Holotype cephalon; dorsal, anterior-oblique and anterior views, $\times 5$.

Figs 2a-c. MGUH 16.526. Paratype cranidium; dorsal, lateral and anterior-oblique views, $\times 5$.

Fig. 3. MGUH 16.530. Paratype free cheek, plan view, $\times 10$.

Figs 4a-c. MGUH 16.527. Paratype cranidium; lateral, dorsal and oblique-ventral views, $\times 5$.

Fig. 5. MGUH 16.528. Paratype cranidium; dorsal view, $\times 5$.

Fig. 6. MGUH 16.529. Paratype cranidium; dorsal view, $\times 5$.

\section{Encrinuroides moderatus (Poulsen, 1934)}

All specimens are from the Cape Schuchert Formation; figs 7-12, 14 from Sankt George Fjord, fig. 13 from Kap Hamilton, Washington Land.

Figs 7a-c. MMH 3273. Holotype cranidium; dorsal, lateral and anterior views, $\times 4$.

Fig. 8. MGUH 16.350. Paratype cranidium, latex cast; plan view, $\times 4$.

Fig. 9. MGUH 16.351. Paratype fragmentary pygidium, latex cast; plan view, $\times 4$.

Figs 10a-c. MMH 3274. Paratype pygidium; posterior, dorsal and lateral wiews, $\times 4$.

Fig. 11. MMH 3275. Paratype fragmentary pygidium, latex cast; dorsal view, $\times 4$.

Figs 12a, b. MGUH 16.531. Paratype fragmentary pygidium; lateral and dorsal views, $\times 4$.

Fig. 13. MGUH 16.532. Paratype pygidium; dorsal view, $\times 4$.

Fig. 14. MGUH 16.533. Paratype pygidium; dorsal view, $\times 8$. 

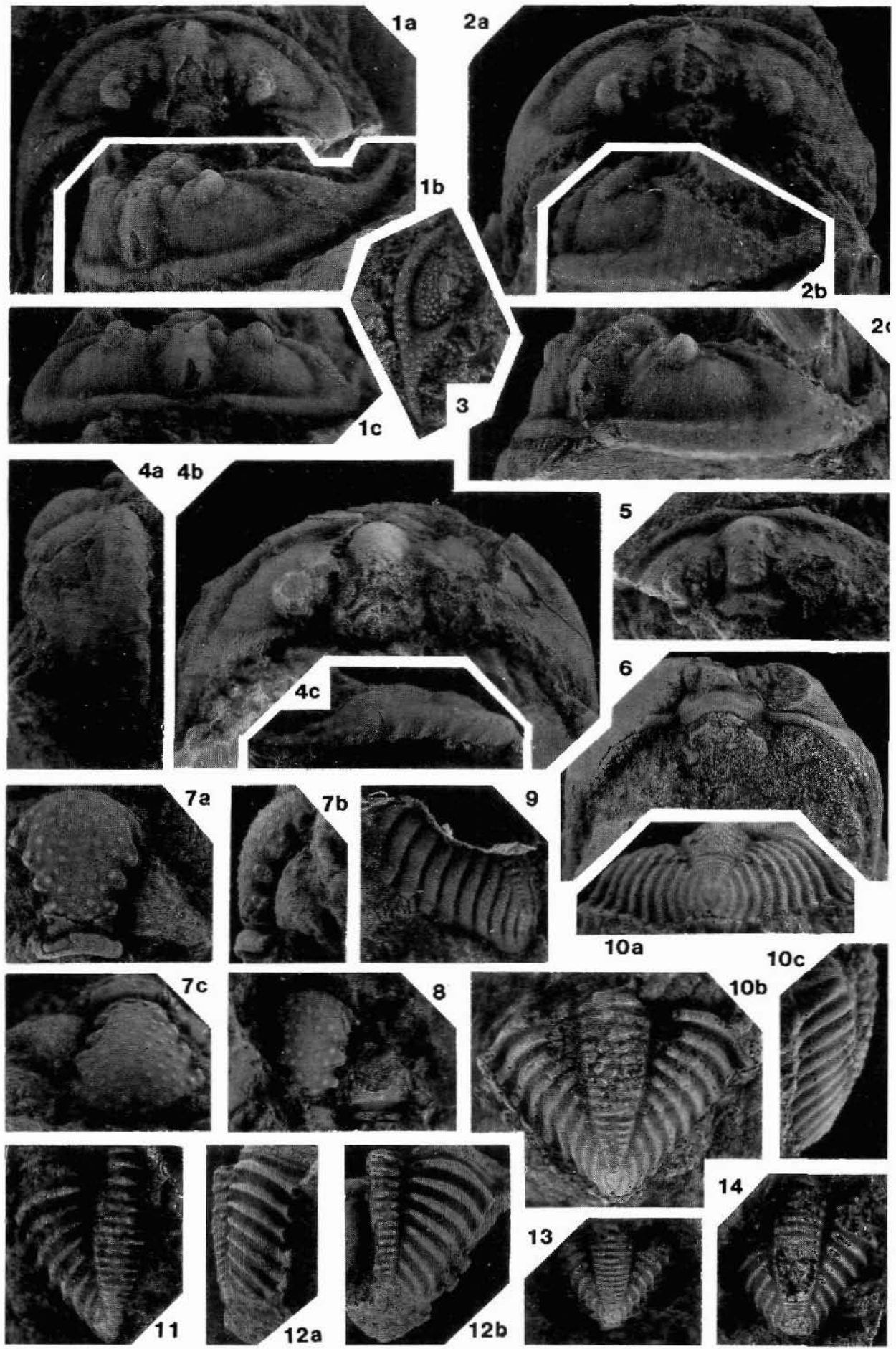